\title{
29. PETROLOGY OF INDURATED SANDSTONES, LEG 18, DEEP SEA DRILLING PROJECT
}

\author{
John B. Hayes, Denver Research Center, Marathon Oil Company, Littleton, Colorado
}

\begin{abstract}
Sandstones from Hole 177A (offshore north end of Vancouver Island) and Sites 178 and 181 (Gulf of Alaska) are compositionally immature feldspathic arenites containing abundant plagioclase. Their compositions lie at the feldspar-rich end of the compositional spectrum for circum-Pacific sandstones. They probably were derived from andesitic-granodioritic-metamorphic arcs of typical arc-trench systems at times when plutons were greatly unroofed and volcanic activity was temporarily diminished.

Sandstones from the Alaskan sites were cemented by calcite very early in diagenesis, which prevented further diagenetic alteration. They have very little silt and clay matrix, and the clays they do have are similar to those in associated shales. The calcite cement prevented grain compaction, so that the sand grains are openly packed in the cement.

In contrast, sandstones from Hole $177 \mathrm{~A}$ had a very complex diagenetic history. A possible 56-meter-thick sand body of probably Early Pliocene age may rest on acoustic basement about 520 meters below the sea floor in 2000 meters of water. The sand body is overlain by submarine-fan turbidites and hemipalagic muds, and may well be filling a submarine channel. Compaction of sand grains during basin subsidence and burial diagenesis reduced original porosity somewhat, but authigenic chlorite filling pores and replacing grains destroyed most of the porosity. After chlorite formation, calcite filled in the little remaining pore space and replaced some sand grains. Then the sediments at Hole $177 \mathrm{~A}$ were uplifted, possibly because of the movements at the triple junction of the American, Pacific, and Juan de Fuca lithospheric plates where the site is located. The sand body and associated rocks were fractured in the process. Acid solutions of unknown origin permeated along hairline fractures and dissolved the chlorite and calcite cements, creating channels of intergranular porosity locally of 30 or 40 percent. Some of this solution porosity was filled later by precipitation of sparry anhydrite.
\end{abstract}

\section{INTRODUCTION}

Most of the sand layers cored on Leg 18 are unconsolidated or extremely friable, but a few indurated sandstones were retrieved from Sites 177,178 and 181. These sandstones typically are interbedded with poorly consolidated sands which otherwise are similar to the sandstones. Mineralogy and texture of unconsolidated sands are presented by Scheidegger et al. (this volume) and Piper (this volume). This study compares the sandstones with associated loose sands, and reports on provenance and diagenesis. Also discussed are aspects of sand depositional environment. Table 1 lists the samples studied. Methods and results for each kind of analysis are presented first, followed by brief discussions of sand deposition and diagenesis.

\section{SAND COMPOSITION AND PROVENANCE}

Two standard thin sections of each sample were stained: one to distinguish between plagioclase and potassium feldspars, the other to distinguish between calcite and dolomite. The samples were impregnated with blue-dyed plastic before sectioning to make pore spaces easily recognizable with uncrossed polarizers. Modal sand compositions obtained by point counting are shown on Table 2 . The many components are grouped into six classes: (a) siliceous resistates, (b) feldspars, (c) labile fragments, (d) other framework grains, (e) cements and matrix, and (f) pore space. Recalculation of the first three classes to total 100 percent permits plotting each sample on the QFL compositional triangle of Figure 1 (Dott, 1964). Disregarding for the moment the problem of fine silt and clay "matrix", all samples cluster within the feldspathic arenite field. Samples from the same site are clearly similar, but the three sites are separated. More analyses would probably blur the distinctions.

The components were point-counted and grouped so as to reconstruct the original, prediagenesis character of the sand as much as possible, a goal Dickinson (1970a) advocated. For example, calcite replaced well over half of 
TABLE 1

Sandstone Samples Studied, Leg 18, Deep Sea Drilling Project

\begin{tabular}{|c|c|c|c|}
\hline $\begin{array}{c}\text { Site, Water } \\
\text { Depth, and Age }\end{array}$ & Sample & $\begin{array}{l}\text { Subbottom } \\
\text { Depth }(\mathrm{m})\end{array}$ & Description \\
\hline $\begin{array}{l}177 \mathrm{~A}-\text { Paul Revere } \\
\text { Ridge off northwest tip } \\
\text { of Vancouver Island }\end{array}$ & $\begin{array}{l}23-3(73-75) \\
26-1(93-95)\end{array}$ & $\begin{array}{l}349.2 \\
450.9\end{array}$ & $\begin{array}{l}\text { Very fine-grained basal sandstone from } 0.3-\mathrm{m} \text {-thick graded turbidite unit in } \\
156-\mathrm{m} \text {-thick turbidite sequence. }\end{array}$ \\
\hline $\begin{array}{l}2006 \text { meters } \\
\text { Early Pliocene }\end{array}$ & $\begin{array}{l}26-1(114-116) \\
26-1(131-133) \\
26-1(148-150)\end{array}$ & $\left.\begin{array}{l}451.1 \\
451.3 \\
451.5\end{array}\right\}$ & $\begin{array}{l}\text { Very fine-grained, slightly friable sandstones; representative of the cored } \\
\text { upper } 0.6 \mathrm{~m} \text { of a presumed massive sandstone layer possibly } 56 \mathrm{~m} \\
\text { thick. }\end{array}$ \\
\hline $\begin{array}{l}178 \text { - Alaskan Abyssal } \\
\text { Plain } \\
4218 \text { meters } \\
\text { Middle Miocene }\end{array}$ & $\begin{array}{l}41(\mathrm{CC}) \\
42(\mathrm{CC}) \\
48(\mathrm{CC}) \\
50(\mathrm{CC})\end{array}$ & $\left.\begin{array}{l}427.5 \\
437.0 \\
535.5\end{array}\right\}$ & $\begin{array}{l}\text { Very fine-grained, calcareous sandstones from thin silty turbidite units } \\
\text { interbedded with dark gray-green muds. } \\
\text { Argillaceous limestone from same kind of sequence as samples above. }\end{array}$ \\
\hline $\begin{array}{l}181 \text { - Lower continental } \\
\text { slope above Aleutian } \\
\text { Trench } \\
3086 \text { meters } \\
\text { Pleistocene? }\end{array}$ & $23(\mathrm{CC})$ & 207.0 & $\begin{array}{l}\text { Very fine-grained, calcareous sandstone from cored interval } 5 \mathrm{~cm} \text { thick; } \\
\text { is either sandstone layer in place or erratic pebble embedded in } \\
\text { Pleistocene? mudstone. }\end{array}$ \\
\hline
\end{tabular}

the original plagioclase in Site 178 and 181 sandstones, but in such a way that the original plagioclase grain boundaries can be recognized (Figure 2). Replacement calcite was counted separately from void-filling calcite, and was included with plagioclase in the final calculation. Carbonate minerals, sparry or micritic, typically precipitate along biotite cleavage planes in circum-Pacific sandstones, and split and swell the biotite flake until the carbonate-biotite mixture is many times the volume of the original biotite. Concurrently, the biotite may alter to clays, and the silicate iron may form finely divided, opaque oxides. The result can be, as with the abundant biotite in Hole 177A sandstones, a nondescript mass of dark, fine-grained clay, calcite, and opaque minerals mixed (Figure 3 ). This material is easily squeezed among the rigid quartz and feldspar grains where even experienced petrographers might count it as clay matrix. If any hint of relict mica fabric could be detected, biotite was counted; otherwise, it was counted as clay and fine-grained carbonate, as shown on Table 2. Thus, the modal analyses have a built-in reversal of diagenetic alteration.

Published modal analyses of Cenozoic and modern sands from the northeast Pacific region (Duncan and Kulm, 1970; Whetten et al., 1969; Garrison et al., 1969; Dott, 1966) suggest that labile fragments, particularly fragments of fine-grained volcanic rocks, typically are more abundant than in the Leg 18 sandstones. If biotite had been excluded from the labile fragment category, as Dickinson (1970a) suggested, percentage of labile fragments for Hole 177A sandstones would be even less than shown. A point of similarity with other circum-Pacific subquartzose sandstones is dominance of plagioclase over K-feldspars, by as much as 8 to 1 . Thus, Leg 18 sandstones probably were derived from rocks chemically similar to those in most circum-Pacific provenances, but extrusive debris was diminished. This probably means that when sands recovered on Leg 18 were deposited, erosion had already stripped away much of the andesitic volcanic cover and unroofed consanguineous granodioritic plutons (Dickinson, 1970b) in the particular source areas. The plutons supplied relatively more monocrystalline quartz and feldspar grains to the sediment load. Another explanation, less likely, is that predepositional chemical and mechanical processing of sand selectively removed volcanic rock fragments, particularly in the very fine sand range into which Leg 18 samples fall. I have seen many very fine-grained sandstones with abundant volcanic rock fragments elsewhere from the northeast Pacific border, in which the suggested predepositional processing did not operate effectively. Also, the general tectonic-topographic setting of high borderlands, narrow shelf, and deep oceanic trench accumulating turbidites argues against long-term storage and compositional processing of very much sand in stream valleys or in the littoral zone.

\section{HEAVY MINERALS}

Samples were crushed and treated with hot 25 percent $\mathrm{HC} 1$ before the heavy minerals (specific gravity $>2.90$ ) were separated. Heavy minerals from the entire sand range $(>62 \mu)$ were examined. Results appear in Table 3. Epidotegroup minerals dominate all the suites. The offshore Alaska samples are distinguished by appreciable amphibole content and small amounts of hypersthene. 
TABLE 2

Petrographic Modal Analyses (400 Points Per Sample) of Selected Sandstones, Leg 18, Deep Sea Drilling Project

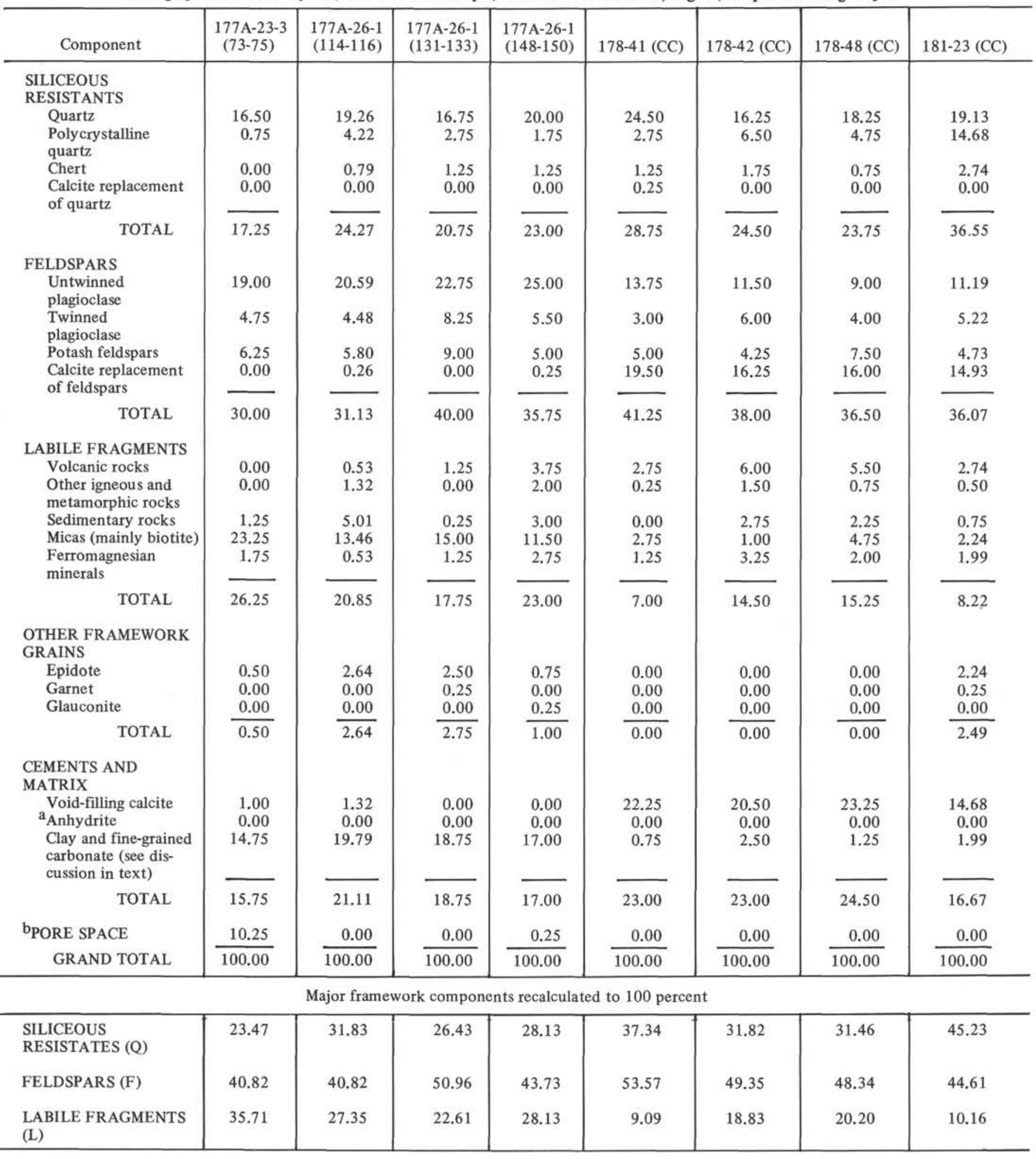

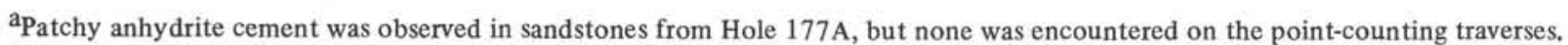

${ }^{b}$ Pore spaces have patchy distribution in sandstones from Hole $177 \mathrm{~A}$; pores were encountered on transverses in some samples and not in others. 


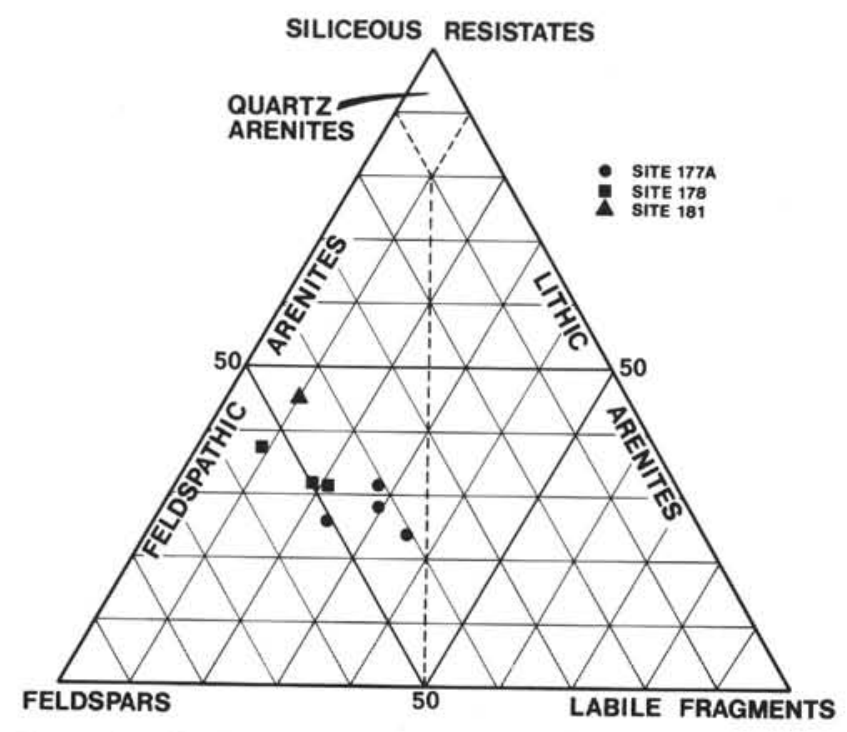

Figure 1. Modal compositions of Leg 18 sandstones on QFL triangle, using classification of Dott (1964).

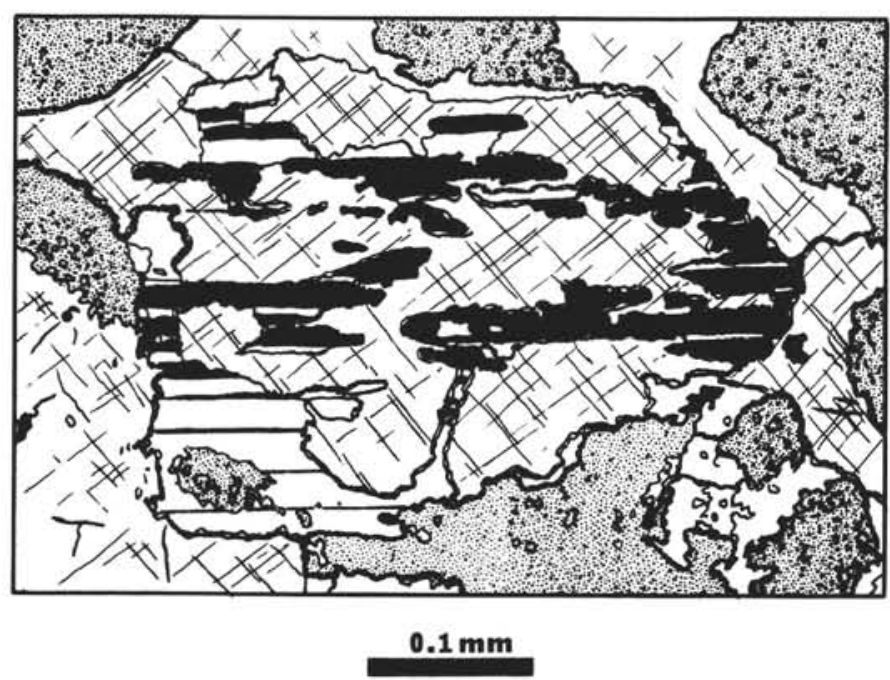

Figure 2. Coarsely crystalline calcite (crosshatched) which partially replaced twinned plagioclase grain and filled intergranular pores (crossed polarizers).

\section{TEXTURAL ANALYSIS}

All samples were crushed as gently as possible and treated with hot 25 percent $\mathrm{HC} 1$, which dissolved carbonates, anhydrite cement, and, unfortunately, some claysize chlorite. A probe-type ultrasonic generator at full power was used for further disaggregation. Each sample was dispersed in sodium hexametaphosphate and split at $62 \mu$ $(4.00 \Phi)$ in the rising current elutriator. Size distributions were determined by sedimentation balance for sand (coarser than $4.00 \Phi$ ) and by pipette analysis for silt and clay (finer than $4.00 \Phi$ ). The clay-silt break is at $4 \mu$ $(8.00 \Phi)$. Weight per cent dissolved in $\mathrm{HC} 1$ was obtained by subtracting the sum of sand, silt, and clay from total sample weight.

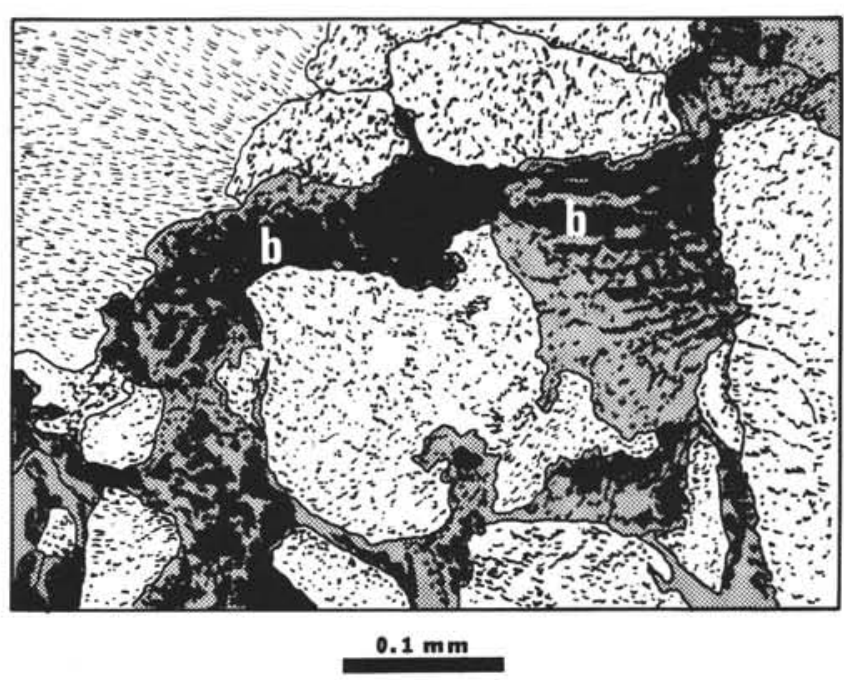

Figure 3. Biotite flakes (b) swollen and altered to mixtures of fine-grained clay and carbonate.

Percentages of sand, silt, clay, and acid-soluble material are shown on Table 4. Computer manipulation of the data provided a wealth of statistical parameters (Table 5). Figure 4 shows representative cumulative distribution curves for the three sites. Excluding 178-50 (CC), which is argillaceous limestone and irrelevant to this discussion, and excluding acid-soluble minerals, the sandstones have from 50 to 75 percent sand, 20 to 40 percent silt, and not very much clay, considerably less than 10 percent in most (Table 4). Sand and silt grains are angular to subangular as seen in thin section, with the less resistant labile grains being less angular. Folk and Ward parameters (Table 5) show the samples to be generally similar. Mean grain size is either coarse silt or very fine sand; sorting is poor; strong fine skewness indicates excessive fine material; and kurtosis is leptokurtic, meaningsorting is poorer in the fine tail of the distribution curve than in the central sandy part. The cumulative distribution curves (Figure 4) show only slight differences between sites.

\section{CEMENTS}

Sandstones from Sites 178 and 181 are thoroughly permeated with sparry calcite as void-filling cement (14 to 23 percent, Table 2), and with calcite replacement of plagioclase (15 to 20 percent). The rocks are hard, dense, and have no obvious porosity. The amount of void-filling cement can be regarded as a measure of minimum porosity when cementation occurred. Cementation apparently occurred fairly early in diagenesis, before very much burial compaction. Mica flakes lie straight and have not been squeezed and crumpled around neighboring rigid grains (cf. Davies, 1967). In the two-dimensional slice of a thin section, most framework grains appear to be free-floating in the carbonate cement. Only a few grains touch at most one or two neighbors. Openness of framework has been accentuated somewhat by calcite replacement at margins of silicate grains.

The carbonate staining technique of Evamy (1963) is sensitive to ferrous iron content of calcite and dolomite, imparting shades of deep blue to dolomite and purple to 
TABLE 3

Heavy Mineral Assemblages $(>62 \mu)$ in Selected Sandstone Samples, Leg 18, Deep Sea Drilling Project

\begin{tabular}{|c|c|c|c|c|}
\hline Component & $177 \mathrm{~A}-23-3(73-75)$ & $177 \mathrm{~A}-26-1(131-133)$ & $178-48(\mathrm{CC})$ & $181-23(\mathrm{CC})$ \\
\hline aOPAQUES & $19 \%$ & $18 \%$ & $7 \%$ & $16 \%$ \\
\hline $\mathrm{b}_{\text {NON-OPAQUES }}$ & & & & \\
\hline Epidote & $47 \%$ & $56 \%$ & $21 \%$ & $37 \%$ \\
\hline $\begin{array}{l}\text { Clinozoisite } \\
\text { (colorless epidote) }\end{array}$ & 42 & 33 & 47 & 39 \\
\hline Hypersthene & 2 & - & 3 & 2 \\
\hline Amphiboles & 4 & - & 27 & 19 \\
\hline Biotite & 2 & 1 & - & 3 \\
\hline Garnets & 1 & 8 & 2 & - \\
\hline Zircon & 2 & 2 & - & - \\
\hline
\end{tabular}

${ }^{\mathrm{a}}$ Opaque percentage determined by counting first 100 grains.

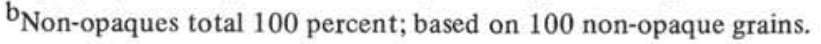

TABLE 4

Size Analysis and Carbonate Mineral Content of Selected Sand stone Samples, Leg 18, Deep Sea Drilling Project

\begin{tabular}{c|c|c|c|c}
\hline Sample & $\begin{array}{c}\text { a Weight \% } \\
\text { Sand }\end{array}$ & $\begin{array}{c}\text { a Weight } \% \\
\text { Silt }\end{array}$ & $\begin{array}{c}a_{\text {Weight } \%} \\
\text { Clay }\end{array}$ & $\begin{array}{c}\mathrm{b}_{\text {Weight } \%} \\
\text { Soluble }\end{array}$ \\
\hline 177A-23-3 (73-75) & 52.99 & 36.22 & 10.79 & 20.70 \\
26-1 (93-95) & 64.00 & 31.06 & 4.93 & 11.70 \\
$26-1(114-116)$ & 64.03 & 30.79 & 5.18 & 13.20 \\
26-1 (148-150) & 66.79 & 28.00 & 5.21 & 13.00 \\
\hline 178-41 (CC) & 56.05 & 39.96 & 4.00 & 38.40 \\
42 (CC) & 67.53 & 27.29 & 5.18 & 37.70 \\
48 (CC) & 50.53 & 42.69 & 6.78 & 39.00 \\
50(CC) & 0.00 & 38.89 & 61.11 & 62.90 \\
(argillaceous & & & & \\
limestone) & & & & \\
181-23 (CC) & 75.43 & 19.85 & 4.72 & 32.40 \\
\hline
\end{tabular}

${ }^{a}$ Sand, silt, and clay total 100 percent of acid-insoluble material. Sand-silt break $=62 \mu$; silt-clay break $=4 \mu$.

${ }^{b}$ Weight loss after treatment with hot 25 -percent $\mathrm{HC} 1$; mostly calcite, but includes some anhydrite in Hole 177A samples, and some clay-size chlorite in all samples.

calcite. The carbonate cement of Site 178 sandstones took such a deep purple-blue stain that ferroan dolomite was suspected; but X-ray diffraction confirmed calcite. To test for ferrous iron substitution, the $a$ unit-cell dimension from $\mathrm{X}$-ray powder photographs was measured. Because $\mathrm{Fe}^{+2}$ is smaller than $\mathrm{Ca}^{+2}$, for which it substitutes, the unit-cell dimension should decrease as $\mathrm{Fe}^{+2}$ content increases. The $a_{\mathrm{o}}$ dimension for pure calcite is $4.9900 \AA$ (Graf, 1961, p. $1285)$, whereas $a_{0}$ for $178-41(\mathrm{CC})=4.940 \AA ; 42(\mathrm{CC})=$ $4.917 \AA$; and $48(\mathrm{CC})=4.924 \AA$. Assuming $\mathrm{Fe}^{+2}$ is the only proxying cation, this means from 4 to 6 mole per cent $\mathrm{FeCO}_{3}$ is in calcite, according to formulae in Goldsmith et al. (1962). A recent paper by Lindholm and Finkelman (1972) related color of stain to iron content in calcite; by their criteria the Site 178 calcite cements should have about 4 to 6 mole percent $\mathrm{FeCO}_{3}$, which correlates well with the cell-demension values. This much ferrous iron content places some constraints on oxidation potential of water which precipitated the calcite cement, but it would be pure speculation to say what caused the negative Eh. Calcite of the argillaceous limestone (178-50 CC) and the cement of Site 181 sandstone both display the normal red-orange stain for non-ferroan calcite. They have $a_{\mathrm{o}}$ closer to ideal; $a_{\mathrm{o}}$ for $178-50(C C)=4.959 \AA ; 181-23(C C)=4.956 \AA$.

Whereas at Sites 178 and 181 calcite cements completely permeated the sands, cementing minerals in Hole 177A sandstones are scattered and patchy. Sparry calcite, nonferroan judging from the red stain, makes up only about 1 percent of Hole 177A sandstones. It is widely scattered as replacement of individual feldspar grains or filling in only a few adjacent voids. I think this calcite came quite late during diagenesis. Patches of coarsely crystalline anhydrite, confirmed by X-ray diffraction, encompass scores of sand grains, with some single anhydrite crystals poikilitically containing several grains. Anhydrite also replaced partially or completely some framework grains. This anhydrite resides in pore spaces which were probably occupied early in diagenesis by authigenic chlorite; the chlorite was dissolved before the anhydrite formed (see section on diagenesis). Anhydrite amounts to about 5 percent in certain thin sections, but oddly, no patches of it were encountered on the point-counting traverses (Table 2).

\section{CLAY MINERALS}

Clay minerals $(<2 \mu)$ were extracted from three of five Hole 177A sandstones and three of four Site 178 sandstones, using methods described by Jackson (1956, Chapter 2) and Hayes (1972, this volume), and analyzed by X-ray diffraction. The clay mineral suite of Hole 177A mudstones in the lower part of the stratigraphic section contains mica, chlorite, mixed-layer mica-montmorillonite, quartz, and plagioclase (see Leg $18 \mathrm{X}$-ray mineralogy studies, this volume). In marked contrast, clay suites of sandstones from Core 26 , Hole $177 \mathrm{~A}$, contain practically pure chlorite, with only traces of quartz, feldspar, and mica. In thin section, chlorite appears as abundant, fine-grained, low-birefringent matrix among the framework grains. Rims of fibrous chlorite line former pores, the centers of which may be filled with randomly oriented chlorite crystallites. Chlorite also replaced altered biotite flakes, volcanic rock fragments, and perhaps pyroxenes and amphiboles. This chlorite is 
TABLE 5

Statistical Parameters from Grain-size Analysis, Leg 18 Sandstones, Deep Sea Drilling Project

\begin{tabular}{|c|c|c|c|c|c|c|c|c|c|}
\hline Sample & $\begin{array}{c}177 \mathrm{~A}-23-3 \\
(73-75)\end{array}$ & $\begin{array}{c}177 \mathrm{~A}-26-1 \\
(93-95)\end{array}$ & $\begin{array}{r}177 \mathrm{~A}-26-1 \\
(114-116)\end{array}$ & $\begin{array}{r}177 \mathrm{~A}-26-1 \\
(148-116)\end{array}$ & $178-41(\mathrm{CC})$ & $178-42(\mathrm{CC})$ & $178-48(\mathrm{CC})$ & $178-50(\mathrm{CC})$ & $181-23(\mathrm{CC})$ \\
\hline \multicolumn{10}{|l|}{$\begin{array}{l}\text { Phi values at } \\
\text { following \% } \\
\text { levels: } \\
\end{array}$} \\
\hline 5 & 3.092 & 2.772 & 2.786 & 2.458 & 2.606 & 2.357 & 2.589 & 6.449 & 2.451 \\
\hline 16 & 3.355 & 3.052 & 3.004 & 2.706 & 2.960 & 2.644 & 2.908 & 7.021 & 2.672 \\
\hline 25 & 3.500 & 3.228 & 3.181 & 2.888 & 3.195 & 2.873 & 3.193 & 7.413 & 2.834 \\
\hline 50 & 3.934 & 3.670 & 3.618 & 3.386 & 3.835 & 3.448 & 3.980 & 8.557 & 3.258 \\
\hline 75 & 4.886 & 4.347 & 4.446 & 4.353 & 4.723 & 4.529 & 4.990 & 9.888 & 3.967 \\
\hline 84 & 6.330 & 4.915 & 5.104 & 4.743 & 5.323 & 5.309 & 5.913 & 10.520 & 4.691 \\
\hline 95 & 11.236 & 7.947 & 8.179 & 8.147 & 7.487 & 8.179 & 8.761 & 11.803 & 7.789 \\
\hline \multicolumn{10}{|l|}{ Inman values (Phi): } \\
\hline $\begin{array}{l}\text { Median dia. ( } 64 \% \\
\text { Efficient) }\end{array}$ & 3.934 & 3.670 & 3.618 & 3.386 & 3.835 & 3.448 & 3.980 & 8.557 & 3.258 \\
\hline $\begin{array}{l}\text { Mean dia. ( } 74 \% \\
\text { Efficient) }\end{array}$ & 4.843 & 3.984 & 4.054 & 3.725 & 4.142 & 3.977 & 4.411 & 8.770 & 3.681 \\
\hline $\begin{array}{l}\text { Deviation (Sorting - } \\
54 \% \text { Efficient) }\end{array}$ & 1.487 & 0.931 & 1.050 & 1.019 & 1.182 & 1.332 & 1.502 & 1.750 & 1.009 \\
\hline Skewness & 0.611 & 0.337 & 0.415 & 0.332 & 0.260 & 0.397 & 0.287 & 0.122 & 0.419 \\
\hline 2nd skewness & 2.172 & 1.814 & 1.775 & 1.881 & 1.025 & 1.366 & 1.128 & 0.325 & 1.844 \\
\hline Kurtosis & 1.738 & 1.779 & 1.567 & 1.793 & 1.065 & 1.185 & 1.054 & 0.530 & 1.644 \\
\hline \multicolumn{10}{|l|}{$\begin{array}{l}\text { Folk and Ward } \\
\text { values (Phi): } \\
\end{array}$} \\
\hline $\begin{array}{l}\text { Mean ( } 88 \% \\
\text { Efficient) }\end{array}$ & 4.540 & 3.879 & 3.909 & 3.612 & 4.039 & 3.801 & 4.267 & 8.699 & 3.540 \\
\hline $\begin{array}{l}\text { Deviation ( } 79 \% \\
\text { Efficient) }\end{array}$ & 1.978 & 1.250 & 1.342 & 1.371 & 1.330 & 1.548 & 1.686 & 1.686 & 1.313 \\
\hline Skewness & 0.702 & 0.495 & 0.553 & 0.503 & 0.378 & 0.511 & 0.418 & 0.167 & 0.558 \\
\hline Kurtosis & 2.409 & 1.895 & 1.747 & 1.591 & 1.309 & 1.441 & 1.408 & 0.887 & 1.931 \\
\hline
\end{tabular}

poorly crystallized, judging from breadth and intensity of basal X-ray reflections. It has a few interstratified vermiculite-like layers which collapse with potassium saturation or heating. Upon heating to $525^{\circ} \mathrm{C}$, the 001 reflection is greatly intensified, shifts to $13.6 \AA$, and all order reflections disappear. The chlorite dissolves in hot $1 N \mathrm{HC}$. The chlorite is one of the low-temperature, authigenic Type-I trioctahedral polytypes, $\mathrm{I} b\left(\beta=97^{\circ}\right)$, described by Hayes (1970). Petrographic and polytype evidences leave little doubt that the chlorite grew in open pore space and replaced framework grains during diagenesis. It could be considered an authigenic cement, like calcite and anhydrite in these same samples.

A similar kind of chlorite is found in the thin turbidite sandstone from Core 23 at the same site. It is even more poorly crystallized than that in Core 26 , is the $\mathrm{I} b_{\mathrm{d}}$ polytype of Hayes (1970), and is accompanied by mixed-layer chlorite-vermiculite-montmorillonite. This mixed-layer clay may result from alteration of biotite described before, and may be the progenitor of the Type-I chlorite. Hayes proposed a diagenetic crystallization, ordering, and stability sequence for Type-I chlorites, going from expansible clays to $\mathrm{I} b_{d}$ to $\mathrm{I} b\left(\beta=97^{\circ}\right)$, to $\mathrm{I} b\left(\beta=90^{\circ}\right)$, the most stable Type-I structure, Hole $177 \mathrm{~A}$ chlorites have gone along the sequence only as far as poorly crystallized $I b\left(\beta=97^{\circ}\right)$. The fact that Core 23 chlorite lagged behind Core 26 chlorite in the crystallization sequence is not due to depth and temperature differences alone, but is also related to amount and ease of fluid migration through the sands early in diagenesis when the chloritic structure began to form. The thin, Core 23 sandstone bed is embraced between mudstones, and is finer grained and more poorly sorted than Core 26 sandstone. The latter, believed to be 56 meters thick, was, and still may be, an important conduit for chemically active fluids. It is suggested that progress of a diagenetic reaction can be controlled by permeability differences.

Clay minerals in Site 178 sandstones tell quite a different story. The clay suite consists of mixed-layer mica-montmorillonite (see Hayes, this volume, for discussion of mixed-layering), mica, chlorite, and vermiculite in subequal amounts, plus minor quartz and feldspar. The sandstone clay suite is virtually identical to that of associated mudstones (Hayes, this volume, Figure 6b, Table $2)$. Lack of permeability due to early diagenetic calcite cementation prevented circulation of fluids and thus prevented alteration of detrital minerals and development of authigenic clays, such as the Type-I chlorite of Hole 177A.

\section{POROSITY}

Unlike Site 178 and 181 sandstones which have no measurable porosity, Hole 177A sandstones average about 31 percent porosity, as measured by standard porosimeter 


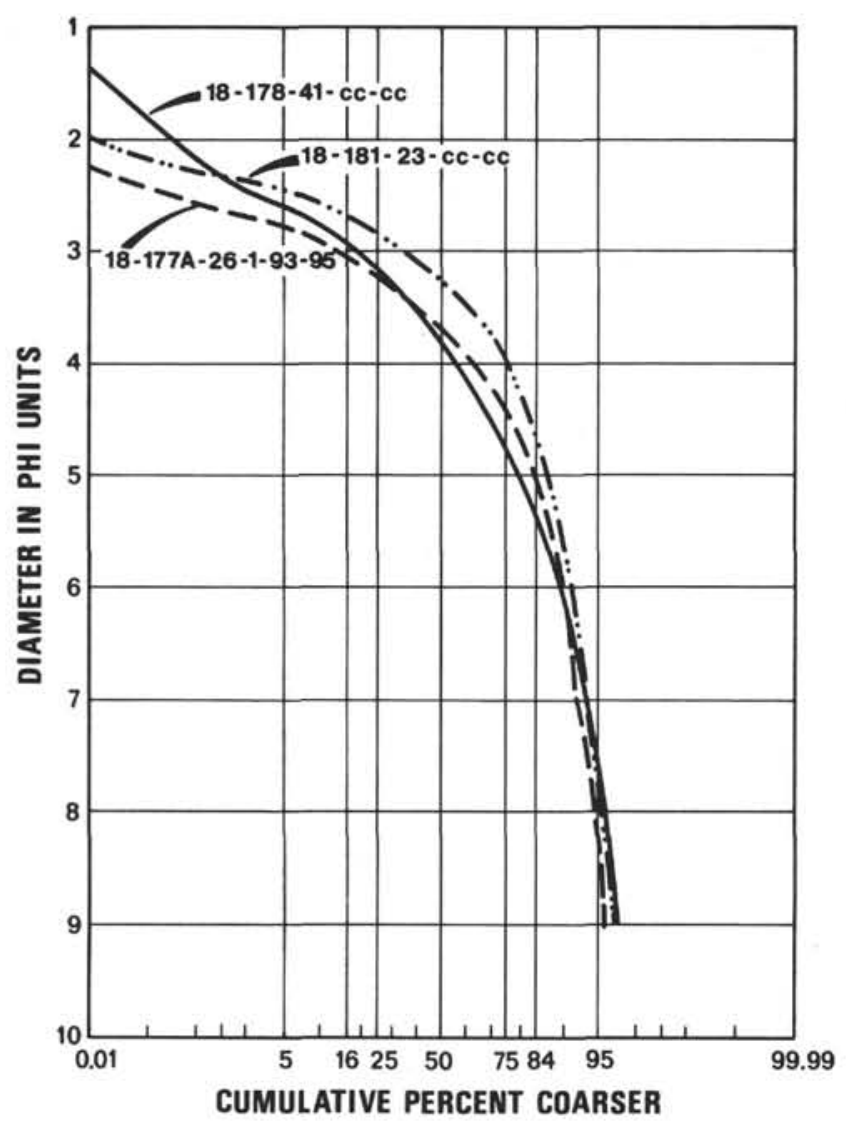

Figure 4. Cumulative size distribution curves for representative Leg 18 sandstones.

techniques at the Marathon Oil Company Research Center. It is puzzling that shipboard GRAPE porosities are about twice this value for the same samples and sandstone intervals (Site 177 Summary, Chapter 6).

Pore spaces appear bright blue in thin section, because the specimens were impregnated with blue-dyed plastic. Intergranular pore spaces are not distributed uniformly throughout Hole 177A sandstones, as one would expect to find in newly deposited or uniformly compacted sand. Rather, visible porosity is concentrated in irregular patches, streaks, and adjacent to hairline fractures. The porous volumes embrace hundreds of sand grains. Within these porous patches the framework grains are loosely packed and well separated; there has been little apparent compaction. Porosity within the porous volumes may be as high as 45 percent by visual estimate, which is quite a bit higher than the 31 percent average measured by porosimeter. In contrast, the areas between the porous patches and streaks have no visible porosity. The framework grains are set in the previously described authigenic chlorite. Actually, these areas have some porosity, maybe 10 to 15 percent; but it is in the form of pores too small for the blue plastic to enter, but not too small for the porosimeter to detect. So porosity measurement of a few-gram rock chip gives only the average, and says nothing about the distribution of porosity. Petrographic evidence strongly suggests that present visible porosity resulted from dissolution of authigenic chlorite cement (see section on diagenesis).

\section{DEPOSITIONAL ORIGIN OF SANDSTONES}

One problem at Hole 177A concerns depositional environment of the apparently massive and possibly 56-meter-thick sandstone in the bottom of the hole (Site 177 Summary, this volume). Core 26 retrieved only the upper 0.6 meters, or about 1 percent of the layer. No vertical trends in mean grain size or sorting are apparent in the three samples from Core 26 (Table 5). It is impossible to determine from these data if the bed is graded or not. The thin turbidite sandstone sample from Core 23 differs from those in Core 26 in being slightly finer grained, more poorly sorted, and accordingly, more strongly fine skewed and more leptokurtic. However, the differences between Core 23 and Core 26 sandstones are not great enough to conclude that the original sands were from different populations nor that transport mechanism and depositional environment, if different, left much impression on particlesize distribution. Mineralogically, Core 23 and Core 26 sandstones are similar, except that the Core 23 turbidite has very biotite-rich laminations due to preferential sorting of platy biotite into finer grain-size classes (Table 2). If the Core 26 sand had been deposited in a markedly different environment from the turbidite, such as in a high-energy, shallow-shelf environment, I would expect more pronounced textural and mineralogical differences. Evidence obtained from Leg 18 cores indicates that much of the sequence drilled in Hole 177A may be submarine fan deposits (Hole 177A, this volume). The apparently massive sandstone of Core 26 could be filling a scour or a distributary channel on a submarine fan.

A problem at Site 181 concerns origin of the $5-\mathrm{cm}$-thick carbonate-cemented sandstone sample from Core 23 (Site 181 Summary, this volume). This occurs in Pleistocene (?), compacted, deformed mudstone below 169 meters, which contains ice-rafted sand and pebbles of various rock types. Is the sandstone a thin bed in place, or is it an erratic pebble of some older sandstone, like, for example, the turbidite sandstones of Site 178? The Site 181 sandstone is mineralogically similar to those from Site 178 (Table 2), even to the heavy minerals (Table 3). Similar Alaskan provenance is indicated for both. Texturally, the Site 181 sandstone is only slightly coarser grained and less poorly sorted than those from Site 178. The biggest difference between the two is composition of calcite cement, with that at Site 178 being distinctly ferroan, and that in the Site 181 sample, non-ferroan. Thus, as with Hole 177A, the question of sand accumulation cannot be answered by textural and mineralogical comparisons alone. Judging from the lack of other calcareous sandstones and the general paucity of carbonate material in the Site 181 section, the calcareous sandstone in question is probably an erratic pebble.

\section{ORIGIN OF MATRIX}

Cummins (1962) argued convincingly that most sands, even deep-sea deposits like those described herein, contain only a few percent fine silt and clay matrix among coarser grains when deposited. $\mathrm{He}$ further maintained that 
abundant fine silt and clay matrix in lithified immature sandstones (graywackes) is the product of a host of diagenetic reactions which reduce average particle size by mechanical and chemical means. Compaction forces the diagenetically produced finer grains to pack tightly as matrix around rigid coarser grains. If so, textural analyses of disaggregated sandstones (Tables 4 and 5) indicate more silt and clay grains than the sands contained when deposited. Four reasons for this are:

1) When the sandstones were crushed, treated with $\mathrm{HC} 1$, and further disaggregated ultrasonically, fine-grained authigenic minerals were dispersed and counted as fine silt and clay. In Hole 177A sandstones, fine-grained authigenic products include (a) fine-grained carbonate and mixed-layer clays from alteration of sand-size biotite (Figure 3 ), and (b) Type-I clay-size chlorite which replaced rock fragments, mineral grains, and grew in pore spaces. (However, some of the authigenic chlorite dissolved in $\mathrm{HC} 1$ and escaped analysis.)

2) Mechanically unstable sand grains were fractured and squeezed during compaction of Hole 177A sands. When the rigorous disaggregation procedures were applied, a certain amount of fine-grained rubble was released.

3) In the calcareous sandstones of Sites 178 and 181, calcite cementation and replacement produced smaller grains from larger ones by calcite wedging along flaws in sand grains, and by incomplete replacement of silicate grains. When the sandstones were acid-treated, these smaller fragments were released.

4) Because Site 178 and 181 sandstones are very hard and tightly cemented with calcite, mechanical crushing of samples before acid treatment surely must have created silt-size slivers. This is an operational problem, not a diagenetic process, but nevertheless it distorts original size distribution.

Even if fine silt and clay matrix were measured by thin-section petrography rather than by mechanical means, fine material produced by diagenesis would confound analysis. Unless pains are taken to ascribe fine-grained "matrix" to the parent detrital grains, as attempted in this study, a clouded impression of original sand texture and mineralogy is obtained.

If, indeed, fine silt and clay matrix is partially diagenetic, the present small amount of clay and fine silt in Leg 18 sandstones is surprising. There must have been even less fine silt and clay in the sands when deposited than exists now. Present clay content averages about 5 percent (Table 4); note on Figure 4 that about 93 percent of the grains are coarser than $7.00 \Phi$ (fine silt). The one exception is the Core 23 thin turbidite sandstone from Hole 177A; it has over 10 percent clay, but it also is the most biotite-rich (Table 2) and has the most carbonate-clay alteration of biotite (Figure 3), as described previously. Diagenetic production of fines modified a more or less normal depositional size distribution, perhaps making it strongly fine skewed and leptokurtic.

There are discrepancies between size analyses and modal analyses of Hole 177A sandstones. Modal analysis shows more so-called clay (14-20 percent, Table 2) than does mechanical analysis (average about 5 percent, Table 4). On the other hand, modal analysis reveals only 1 or 2 percent recognizable calcite (Table 2), but weight loss with $\mathrm{HC} 1$ is 11 to 20 percent. There are two reasons for these discrepancies: (1) much of the so-called clay in thin section is really fine-grained carbonate mixed with clay because of biotite alteration, and is dissolved in $\mathrm{HC} 1$ before mechanical analysis, and (2) this fine-grained carbonate is not counted as thin-section carbonate, but is does dissolve along with anhydrite, authigenic chlorite, and the small amount of sparry calcite to give appreciable acidization weight loss.

\section{DIAGENESIS - A STUDY IN CONTRASTS}

Observations and interpretations regarding diagenetic processes and products are scattered throughout this report. This section consolidates these as a summary of diagenetic history, which, for Hole 177A sandstones, is markedly more complex than that of Site 178 and 181 sandstones.

Actually, diagenetic history of Hole 177A sands is so complex in detail that probably only a few of the major events have been recognized. When Hole 177A sands were laid down, they had only a few percent fine silt and clay, were compositionally immature feldspathic arenites, and had initial porosities of about 40 percent. One of the first things to happen shortly after burial was modest compaction and reduction of porosity to about 30 or 35 percent, accomplished mainly by grains shaking down into better packing, rather than by grains breaking and squeezing. Then, as this process was going on, authigenic chlorite or some progenitor mixed-layer clay began crystallizing as thin films around pores, small amounts of detrital clay began altering to chlorite, and certain sand grains were chloritized. Biotite began swelling by addition of fine-grained carbonate, and also altering to chlorite. Along with chloritization, compaction by grain squeezing and fracturing went ahead while the sediments were buried hundreds of feet beneath the sea floor. Toward the end of compaction, calcite selectively replaced entire sand grains, mainly plagioclase, and filled a few remaining pores. These processes eventually produced sandstone with no original intergranular pores left, because they had been collapsed by grain squeezing or filled with authigenic clay or other cements.

Then, about 2 million years ago, Paul Revere Ridge, where Hole 177A is located, began to be uplifted (Site 177A Summary, this volume). Uplift was due, no doubt, to complex plate motion at the triple junction of the Pacific, American, and Juan de Fuca plates where the site is situated. Faulting and fracturing of the sediments resulted, including the thick sand body of Core 26. The recovered cores have abundant slickensides. Acidic fluids of unknown origin began to permeate along the fractures, dissolving authigenic chlorite and carbonates, and creating considerable intergranular porosity. In thin section, such porosity is centered about tiny hairline fractures. As the acid fluids worked outward from the fractures, they digested soluble cements in all directions to give the mottled, patchy porosity distribution described in the section on porosity. Some time later, the coarsely crystalline anhydrite precipitated; it is found filling only the solution porosity.

Compared to complex diagenesis of Hole 177A sands, diagenetic history of Site 178 and 181 sands is quite simple. They, too, had little detrital silt and clay, were feldspathic 
arenites, and had high porosity when deposited. They, too, lost some porosity very early in burial by grains settling into more efficient packing. But then, in a geologic instant so it seems, the remaining pore space was completely filled by calcite cement, and calcite also partially replaced plagioclase. No more grain compaction, no alteration of detrital clay, no swelling of biotite, no authigenic clay formation - in short, no more diagenesis could take place. Cement effectively embalmed the original character of the sands.

The heavy mineral assemblages of consolidated sandstones probably were influenced by diagenesis, judging from comparisons with heavy mineral assemblages from associated unconsolidated sands. Scheidegger et al. (this volume) reported 42.5 percent amphibole and 32.5 percent pyroxene for an unconsolidated sand from Core 48 at Site 178; a consolidated, calcite-cemented sandstone from the same core (Table 3 ) contains only 27 percent amphibole and 3 percent pyroxene in the heavy mineral suite. Thin-section evidence suggests that replacement of pyroxenes and amphiboles by calcite is one way to explain the difference. In Hole 177A, there is a remarkable change from an amphibole-pyroxene dominated suite in Core 21 and above to an epidote-rich suite in Core 23 and below, from which pyroxenes and amphiboles are virtually absent (Table 3 and Scheidegger et al., this volume). Whether this change is sharp or transitional is not known, because there are 75 meters of section between samples from Core 21 and Core 23. This change in heavy minerals could mean a change in provenance, but diagenesis is more likely the cause. Thin sections of consolidated sandstones in Cores 23 and 26 show that partial to complete chloritization of pyroxenes and amphiboles was an important process. Enough remnants of pyroxenes and amphiboles are present to give a few per cent of these minerals "reconstructed" in the modal analyses (Table 2). But these remnants failed to appear in the separated heavy mineral suite, because they were too small or because they did not survive the acid treatment. Unconsolidated sands in Core 23 and below, which lack pyroxenes and amphiboles, may have been chloritized and consolidated at one time; but they had so much chlorite dissolved in the manner described that they now appear unconsolidated.

\section{CONCLUSIONS}

1. Sandstones (nine samples analyzed) from Sites 177, 178 , and 181 are compositionally immature feldspathic arenites, containing abundant plagioclase. Their compositions lie at the feldspar-rich end of the compositional spectrum for circum-Pacific sandstones. They probably were derived from andesitic-granodioritic-metamorphic arcs of typical arc-trench systems at times when plutons were greatly unroofed and volcanic activity was temporarily diminished.

2. These sandstones are poorly sorted and very fine grained. They probably had only a few percent fine silt and clay detrital matrix when deposited.

3. Clay minerals in Hole $177 \mathrm{~A}$ mudstones are typical detrital suite for the northeast Pacific (mica, chlorite, mixed-layer mica-montmorillonite); whereas, poorly crystallized, low-temperature, Type-I authigenic chlorite, accompanied by mixed-layer chlorite-vermiculitemontmorillonite, is the dominant clay mineral of Hole $177 \mathrm{~A}$ sandstones. Degree of crystallographic ordering of authigenic chlorite is directly related to ease of ionic migration and fluid flow through the sand, as controlled by mean grain size and sorting. In contrast, clay minerals from Site 178 and 181 sandstones are identical to clay minerals in associated mudstones-again, the typical northeast Pacific detrital suite. Early diagenetic cementation of these sandstones protected the detrital clay suite from diagenetic alteration and prevented formation of authigenic clays.

4. Petrographic data shed no light on the erratic pebble versus in-place origin of the sandstone from Site 181. Likewise, no clear-cut petrographic evidence can be found indicating the depositional environment of the presumed 56-meter-thick sandstone near the bottom of Hole 177A.

5. Sandstones from Hole 177A have undergone compaction, cementation by authigenic chlorite and calcite, replacement of framework grains, loss of original porosity, dissolution of cements by acid solutions moving along tectonically induced hairline fractures which recreated some of the original porosity, and finally, some recementation by coarsely crystalline anhydrite. In contrast, Site 178 and 181 sandstones were completely cemented by calcite very early in diagenesis, which prevented further diagenetic alteration.

\section{ACKNOWLEDGMENTS}

I am greatly indebted to D. M. Poole, C. Heubach, and K. M. Swanson, colleagues in Marathon Oil Company Research Center, for their able assistance with textural, petrographic, heavy mineral, and X-ray analyses. D. B. MacKenzie of Marathon reviewed the manuscript and made suggestions for improvement. I appreciate being given the opportunity to work on these interesting sandstones by L. D. Kulm and the staff of Leg 18, DSDP.

\section{REFERENCES}

Cummins, W. A., 1962. The greywacke problem. Liverpool-Manchester Geol. 3, 51.

Davies, D. K., 1967. Origin of friable sandstone - calcareous sandstone rhythms in the Upper Lias of England. J. Sed. Petrology. 37, 1179.

Dickinson, W. R., 1970a. Interpreting detrital modes of graywacke and arkose. J. Sed. Petrology. 40, 695.

1970b. Relations of andesites, granites, and derivative sandstones to arc-trench tectonics. Rev. Geophys. Space Phys. 8, 813.

Dott, R. H., Jr., 1964. Wacke, graywacke and matrix what approach to immature sandstone classification? J. Sed. Petrology. 34, 625.

1966. Eocene deltaic sedimentation at Coos Bay, Oregon. J. Geology. 74, 373.

Duncan, J. R., and Kulm, L. D., 1970. Mineralogy, provenance, and dispersal history of late Quaternary deep-sea sands in Cascadia Basin and Blanco Fracture Zone off Oregon. J. Sed. Petrology. 40, 874.

Evamy, B. D., 1963. The application of a chemical staining technique to a study of dedolomitisation. J. Sediment. 2,164 .

Garrison, R. E., Luternauer, J. L., Grill, E. V., MacDonald, R. D., and Murray, J. W., 1969. Early diagenetic cementation of Recent sands, Fraser River delta, British Columbia. Sedimentology. 12, 27. 
Goldsmith, J. R., Graf, D. L., Witters, J., and Northrop, D. A., 1962. Studies in the system $\mathrm{CaCO}_{3}-\mathrm{MgCO}_{3}-\mathrm{FeCO}_{3}$ : 1. Phase relations; 2. A method for major-element spectrochemical analysis; 3 . Compositions of some ferroan dolomites. J. Geology. 70, 659.

Graf, D. L., 1961. Crystallographic tables for the rhombohedral carbonates. Am. Mineralogist. 46, 1283.

Hayes, J. B., 1970. Polytypism of chlorite in sedimentary rocks. Clays and Clay Minerals. 18, 285.
Jackson, M. L., 1956. Soil chemical analysis-advanced course, published by the author, Madison, Wisc., 991 p.

Lindholm, R. C., and Finkelman, R. B., 1972. Calcite staining: semiquantitative determination of ferrous iron. J. Sed. Petrology. 42, 239.

Whetten, J. T., Kelley, J. C., and Hanson, L. G., 1969. Characteristics of Columbia River sediment and sediment transport. J. Sed. Petrology. 39, 1149. 